\title{
Front Matter: Volume 8411
}

, "Front Matter: Volume 8411," Proc. SPIE 8411, Advanced Topics in Optoelectronics, Microelectronics, and Nanotechnologies VI, 841101 (1 November 2012); doi: 10.1117/12.2014362

SDIE Event: Advanced Topics in Optoelectronics, Microelectronics, and SPIE. Nanotechnologies 2012, 2012, Constanta, Romania 


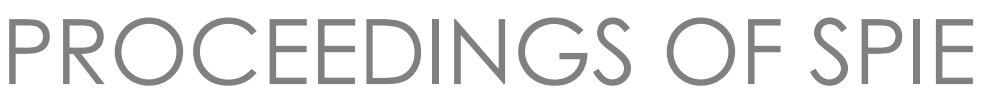

\title{
Advanced Topics in Optoelectronics, Microelectronics, and Nanotechnologies VI
}

\author{
Paul Schiopu \\ Razvan Tamas \\ Editors
}

\section{3-26 August 2012 \\ Constanta, Romania}

Organized by

Politehnica University of Bucharest- Optoelectronics Research Center (Romania) Constanta Maritime University (Romania)

Sponsored by

Romanian Ministry of Education and Research (ANCS - Romania)

Teamnet International (Romania)

Politehnica University of Bucharest (Romania)

Constanta Maritime University (Romania)

Electromagnetica Goldstar S.R.L. (Romania)

ANTRICE (Romania)

Cooperating Organization and Publisher

SPIE 
The papers included in this volume were part of the technical conference cited on the cover and title page. Papers were selected and subject to review by the editors and conference program committee. Some conference presentations may not be available for publication. The papers published in these proceedings reflect the work and thoughts of the authors and are published herein as submitted. The publisher is not responsible for the validity of the information or for any outcomes resulting from reliance thereon.

Please use the following format to cite material from this book:

Author(s), "Title of Paper," in Advanced Topics in Optoelectronics, Microelectronics, and Nanotechnologies VI, edited by Paul Schiopu, Razvan Tamas, Proceedings of SPIE Vol. 8411 (SPIE, Bellingham, WA, 2012) Article CID Number.

ISSN: 0277-786X

ISBN: 9780819490896

Published by

SPIE

P.O. Box 10, Bellingham, Washington 98227-0010 USA

Telephone +1 3606763290 (Pacific Time) · Fax +1 3606471445

SPIE.org

Copyright (@ 2012, Society of Photo-Optical Instrumentation Engineers.

Copying of material in this book for internal or personal use, or for the internal or personal use of specific clients, beyond the fair use provisions granted by the U.S. Copyright Law is authorized by SPIE subject to payment of copying fees. The Transactional Reporting Service base fee for this volume is $\$ 18.00$ per article (or portion thereof), which should be paid directly to the Copyright Clearance Center (CCC), 222 Rosewood Drive, Danvers, MA 01923. Payment may also be made electronically through CCC Online at copyright.com. Other copying for republication, resale, advertising or promotion, or any form of systematic or multiple reproduction of any material in this book is prohibited except with permission in writing from the publisher. The CCC fee code is 0277-786X/12/\$18.00.

Printed in the United States of America.

Publication of record for individual papers is online in the SPIE Digital Library.

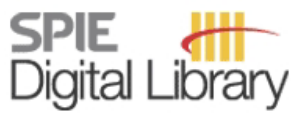

SPIEDigitalLibrary.org

Paper Numbering: Proceedings of SPIE follow an e-First publication model, with papers published first online and then in print and on CD-ROM. Papers are published as they are submitted and meet publication criteria. A unique, consistent, permanent citation identifier (CID) number is assigned to each article at the time of the first publication. Utilization of CIDs allows articles to be fully citable as soon as they are published online, and connects the same identifier to all online, print, and electronic versions of the publication. SPIE uses

a six-digit CID article numbering system in which:

- The first four digits correspond to the SPIE volume number.

- The last two digits indicate publication order within the volume using a Base 36 numbering

system employing both numerals and letters. These two-number sets start with 00, 01, 02, 03, 04, $05,06,07,08,09,0 A, 0 B \ldots 0 Z$, followed by 10-1Z, 20-2Z, etc.

The CID Number appears on each page of the manuscript. The complete citation is used on the first page, and an abbreviated version on subsequent pages. Numbers in the index correspond to the last two digits of the six-digit CID Number. 


\title{
Contents
}

\author{
xi Conference Committee \\ $\mathrm{xv}$ Introduction
}

\section{KEYNOTE SESSION}

841102 The mechanical action of the spin part of the internal energy flow (Invited Paper) [8411-1] O. V. Angelsky, Chernivtsi National Univ. (Ukraine); A. Ya. Bekshaev, Odessa National Univ. (Ukraine); P. P. Maksimyak, A. P. Maksimyak, C. Yu. Zenkova, N. V. Gorodynska, Chernivtsi National Univ. (Ukraine)

841103 Characterzation of Ge-Sb-Te phase-change memory materials (Invited Paper) [841 1-2] M. Iovu, E. Colomeico, V. Benea, D. Harea, Institute of Applied Physics (Moldova)

841104 Metamaterials modelling, fabrication, and characterisation techniques (Invited Paper) [841 1-3]

R. Malureanu, M. Zalkovskij, A. Andryieuski, A. Novitsky, A. Ivinskaya, P. U. Jepesen, Technical Univ. of Denmark (Denmark); A. Popescu, D. Savastru, INOE 2000 (Romania); A. Lavrinenko, Technical Univ. of Denmark (Denmark)

841105 Characterization of canine oocytes using absorption/transmission measurements (Invited Paper) [841 1-4]

G. C. Vasile, I. A. Bîrțoiu, I.-M. N. Vasile, M. Mihăilescu, N. N. Puşcaş, Politehnica Univ. of Bucharest (Romania)

$841106 \quad \mathbf{R}^{3}$ measurement by white light interferometry (Invited Paper) [8411-5] M. Bojan, D. Apostol, N. Cernescu, I. Iordache, V. Damian, National Institute for Lasers, Plasma and Radiation Physics (Romania); P. Schiopu, Politehnica Univ. of Bucharest (Romania)

841107 Manipulation of three particle cooperative emission in single- and two-photon interaction through the vacuum field (Invited Paper) [8411-6]

N. A. Enaki, Institute of Applied Physics (Moldova)

\section{DIFFRACTIVE, MICRO-OPTICS, AND OPTICAL SIGNAL PROCESSING}

841108 Using inhomogeneity in light energy distribution for estimating the degree of coherence of superposing waves (Invited Paper) [841 1-7]

C. Yu. Zenkova, M. P. Gorsky, I. V. Soltys, P. O. Angelsky, Chernivtsi National Univ. (Ukraine)

841109 Autocorrelation diagnostics of phase singularities in diffracted optical fields [841 1-8] Ch. V. Felde, M. V. Oleksyuk, P. V. Polyanskii, H. V. Bogatyryova, Chernivtsi National Univ. (Ukraine) 
$84110 \mathrm{~A}$ Continuous wavelet transform for $\mathbf{d}$-space distribution analysis in nanocrystallic materials (Invited Paper) [8411-9]

M. Wielgus, Institute of Electron Technology (Poland) and Institute of Micromechanics and Photonics (Poland); J. Grochowski, Institute of Electron Technology (Poland) and Institute of Microelectronics and Optoelectronics (Poland); E. Kamińska, Institute of Electron Technology (Poland); K. Patorski, Institute of Micromechanics and Photonics (Poland)

$8411 \mathrm{OB}$ The system of polarization-phase filtering of laser images of biological fluids (Invited Paper) [8411-10]

Yu. A. Ushenko, M. Sidor, Chernivtsi National Univ. (Ukraine)

8411 OC Scale-selective polarization cartography of biological polycrystalline net [8411-11]

Yu. A. Ushenko, O. Ya. Wanchuliak, Chernivtsi National Univ. (Ukraine)

8411 OD Pattern recognition in embedded systems [8411-12]

P. Şchiopu, Politehnica Univ. of Bucharest (Romania); A. Bogdan, Advanced Technologies Institute (Romania); L. Mateescu, Military Equipment and Technologies Research Agency (Romania)

8411 OF Sampling theorem: the cornerstone of discrete optics (Invited Paper) [8411-14] P. C. Logofatu, V. Nascov, National Institute for Lasers, Plasma and Radiation Physics (Romania)

$84110 G \quad$ Using the passively mode-locked soliton fiber laser linear cavity to investigate transparent media [8411-15]

I. R. Schiopu, B. Comănescu, S. C. Optoelectronica - 2001 S.A. (Romania); P. Schiopu, Politehnica Univ. of Bucharest (Romania)

$84110 \mathrm{~J}$ Multidimensional laser microscopy of polarization-singular structure of phaseinhomogeneous layers for diagnostics and classification of their optical properties [8411-18]

A. G. Ushenko, A. V. Dubolazov, O. Yu. Novakovska, Chernivtsi National Univ. (Ukraine)

8411 OK Calculation of the optical constants of amorphous $\left[\left(\mathrm{As}_{2} \mathrm{~S}_{3}\right):\left(\mathrm{As}_{2} \mathrm{Se}_{3}\right)\right]_{1-\mathrm{x}}: \mathrm{Sn}_{\mathrm{x}}$ thin films [8411-19]

O. V. Iaseniuc, Institute of Applied Physics (Moldova)

$8411 \mathrm{OL} \quad$ Spectroscopic study of amorphous $\mathrm{As}_{2} \mathrm{Se}_{3}: \mathrm{Sn}_{\mathrm{x}}$ and $\left(\mathrm{As}_{2} \mathrm{~S}_{1.5} \mathrm{Se}_{1.5}\right)_{1-\mathrm{x}}: \mathrm{Sn}_{\mathbf{x}}$ thin films [841 1-20] O. V. Iaseniuc, D. V. Harea, M. S. Iovu, E. P. Colomeico, E. Harea, I. A. Cojocaru, Institute of Applied Physics (Moldova); D. F. Shepel, Institute of Chemistry (Moldova); A. Meshalkin, Institute of Applied Physics (Moldova)

8411 OM Polariscopic and interferometric measurements of the mechanical stress [8411-21] A. G. Ilie, M. Mihailescu, Politehnica Univ. of Bucharest (Romania); R. A. Gabor, ICECHIM (Romania); O. Curcan, S. C. Optoelectronica-2001 S.A. (Romania); C.-A. Nicolae, ICECHIM (Romania)

$84110 \mathrm{~N}$ Holographic screening of dynamic real scenes [8411-22]

C. G. Schiriac, N. Mihale, M. Mihailescu, Politehnica Univ. of Bucharest (Romania)

841100 System of polarization correlometry of biological liquids [8411-23]

V. A. Ushenko, Chernivtsi National Univ. (Ukraine) 
8411 OP Fourier phasometry of biological polycrystalline networks coherent images [841 1-24]

P. O. Angelsky, A. O. Karachevtsev, Chernivtsi National Univ. (Ukraine)

$84110 Q \quad$ Design and simulation of infrared optical logic gates based on Si photonic crystal waveguides for high density photonic integrated circuits [8411-25]

D. E. Tranca, Politehnica Univ. of Bucharest (Romania); R. Tomescu, IMT Bucharest

(Romania); P. Schiopu, Politehnica Univ. of Bucharest (Romania)

8411 OR Phase-shifting interferometry with a reflective diffraction grating for adaptive optics [8411-26]

F. Garoi, P. C. Logofatu, D. Apostol, C. Udrea, National Institute for Lasers, Plasma and Radiation Physics (Romania)

8411 OS Photonic logic gates with simultaneous processing of multiple signals [8411-27]

V. Degeratu, S. Degeratu, O2Micro (Romania) and Politehnica Univ. of Bucharest

(Romania); P. Şchiopu, Politehnica Univ. of Bucharest (Romania)

SENSORS, MICROSYSTEMS, AND INSTRUMENTS

8411 OT Photothermal calorimetric techniques applied to condensed matter materials (Invited Paper) [8411-28]

D. Dadarlat, National Institute for Research and Development of Isotopic and Molecular Technologies (Romania)

$84110 \mathrm{U}$ Short term wind speed forecasting based on cluster analysis and ANN in wind farms (Invited Paper) [8411-29]

I. lleană, M. Muntean, M. Rîşteiu, 1 Decembrie 1918 Univ., Alba lulia (Romania)

8411 OV Sensors: the road from signal to information [8411-30]

A.-C. Marinica, Politehnica Univ. of Bucharest (Romania)

8411 OW Device design to scan a dental imprint (Invited Paper) [8411-31]

A. O. I. Trufasu, E. A. R. Lepadatu, Politehnica Univ. of Bucharest (Romania)

$84110 X$ Digital illumination system for a zoom riflescope [8411-32]

D. Granciu, D. N. Mitricică, S.C. IOR S.A. (Romania)

841111 Three-stage ring oscillator with organic transistors [8411-36]

A. Bonea, Politehnica Univ. of Bucharest (Romania); T. Hassinen, VTT Technical Research

Ctr. of Finland (Finland); P. Svasta, Politehnica Univ. of Bucharest (Romania)

841112 LED switching module with organic devices [841 1-37]

A. Bonea, Politehnica Univ. of Bucharest (Romania); T. Hassinen, VTT Technical Research

Ctr. of Finland (Finland); N. Codreanu, P. Svasta, Politehnica Univ. of Bucharest (Romania)

841113 Characterization of SAW filters based on $\mathrm{GaPO}_{4}$ [8411-38]

P. Schiopu, A. Manea, N. Grosu, A.-I. Craciun, A. Craciun, Politehnica Univ. of Bucharest (Romania) 
841114 Development of optoelectronics in Politehnica University of Bucharest [8411-39]

P. Schiopu, N. Grosu, I. Cristea, A. Manea, A. Craciun, Politehnica Univ. of Bucharest (Romania)

841115 Hybrid supercapacitor-battery electric system for powering an electric motor [841 1-40] B. Mihailescu, A. Bonea, A. Brodeala, A. Vasile, P. Svasta, Politehnica Univ. of Bucharest (Romania)

841116 Differential inductive displacement sensor with integrated electronics and infrared communication capabilities [8411-41]

A. Drumea, Politehnica Univ. of Bucharest (Romania); M. Blejan, Research Institute for Hydraulics and Pneumatics, INOE200-IHP (Romania); C. Ionescu, Politehnica Univ. of Bucharest (Romania)

841117 Mutagenic contaminants bioaccumulation detection at ultratrace levels from complex biological matrices [841 1-42]

M. H. Kovacs, Z. Moldovan, National Institute for Research and Development of Isotopic and Molecular Technologies (Romania); D. Ristoiu, Babeş-Bolyai Univ. (Romania)

841118 Comparison of two RFID antennas based on FR4-Cu and Kapton-Ag [8411-43]

C.-A. Tămaş, O2Micro (Romania); M. Pantazică, Politehnica Univ. of Bucharest (Romania); V. Chesaru, O2Micro (Romania)

841119 Layer thickness measurement using ultrasonic waves [8411-45]

P. Schiopu, C. Schiopu, V. Sorescu, V. Feies, Politehnica Univ. of Bucharest (Romania)

\section{ADVANCED MATERIALS AND NEW TECHNOLOGIES}

$84111 \mathrm{~A}$ Photouminescence and optical properties of $\mathrm{PVP} / \mathrm{Tb}(\mathrm{TTA})_{2}\left(\mathrm{Ph}_{3} \mathrm{PO}\right)_{2} \mathrm{NO}_{3}$ nanocomposites (Invited Paper) [8411-46]

V. I. Verlan, M. S. Iovu, I. Culeac, Y. H. Nistor, Institute of Applied Physics (Moldova);

C. I. Turta, V. E. Zubareva, Institute of Chemistry (Moldova)

8411 1B Electrical characterization of ink-jet printed organic capacitors on flexible substrate [841 1-47]

A. Brodeala, A. Bonea, Politehnica Univ. of Bucharest (Romania); A. Alcade, Autonomous Univ. of Barcelona (Spain); B. Mihailescu, A. Vasile, P. Svasta, Politehnica Univ. of Bucharest (Romania)

$84111 \mathrm{C}$ Comparison of various structures of CMOS photodiodes in terms of dark current, photocurrent, and quantum efficiency [8411-48]

A. Drăgulinescu, Politehnica Univ. of Bucharest (Romania)

8411 1D Applications of CMOS image sensors: state-of-the-art [8411-49]

A. Drăgulinescu, Politehnica Univ. of Bucharest (Romania)

8411 1E Laser methods for pharmaceutical pollutants removal (Invited Paper) [8411-50]

A. Smarandache, A. Militaru, National Institute for Lasers, Plasma and Radiation Physics (Romania); H. Goker, Ankara Univ. (Turkey); A. Pascu, M.-L. Pascu, National Institute for Lasers, Plasma and Radiation Physics (Romania) 
$8411 \mathrm{lF}$ Possibilities of using a $1070 \mathrm{~nm}$ laser in machining of some metallic materials (Invited Paper) [8411-51]

L. Slătineanu, O. Dodun, M. Coteață, Gheorghe Asachi Technical Univ. of Iaşi (Romania); I. B. Grigoraş, Ştefan cel Mare Univ. of Suceava (Romania); L. Gherman, Gheorghe Asachi Technical Univ. of Iaşi (Romania)

8411 1G Polyaniline/poly (aniline-N-propansulfonic acid) composites by template polymerization of aniline [8411-52]

A.-M. Catargiu, M. Grigoras, P. Poni Institute of Macromolecular Chemistry (Romania)

$8411 \mathrm{H} \mathrm{New} \mathrm{practice-oriented} \mathrm{approach} \mathrm{for} \mathrm{teaching} \mathrm{organic} \mathrm{and} \mathrm{printed} \mathrm{electronics} \mathrm{in} \mathrm{the}$ electronics/optoelectronics university education [8411-53]

N. Codreanu, M. Vladescu, C. Ionescu, A. Bonea, Politehnica Univ. of Bucharest (Romania)

841111 Interconnection of germanium photovoltaic cells using vapor phase soldering technology [8411-54]

I. Plotog, M. Vladescu, Politehnica Univ. of Bucharest (Romania)

$84111 \mathrm{~J}$ The effects of UV irradiation in azo-derivatives [8411-55]

I. Ionita, Valahia Univ. of Târgovişte (Romania); A.-M. Albu, Politehnica Univ. of Bucharest (Romania) and Costin D. Nenitescu Ctr. for Organic Chemistry (Romania); C. Radulescu, I.-D. Dulama, Valahia Univ. of Târgovişte (Romania); I. Gavrila, Politehnica Univ. of Bucharest (Romania)

8411 1L Kinetic parameters and thermal stability of metalloporphyrins [8411-57] S.-F. Pop, R.-M. Ion, ICECHIM (Romania)

$84111 \mathrm{M}$ Characterization of spin-coated thin polymer films by optical spectroscopy [8411-58] A. Meshalkin, D. Harea, O. Iaseniuc, Institute of Applied Physics (Moldova); D. Shepel, L. Bets, Institute of Chemistry (Moldova)

$84111 \mathrm{P}$ Porphyrin-zeolite nanomaterials for hydrogen peroxide decomposition [841 1-61]

V. A. Faraon, Valahia Univ. of Târgovişte (Romania) and ICECHIM (Romania); S. F. Pop, R. M. Senin, ICECHIM (Romania); S. M. Doncea, R. M. Ion, Valahia Univ. of Târgovişte (Romania) and ICECHIM (Romania)

$84111 Q \quad K n o w l e d g e$ step in advanced materials: Polymeric Wikia [8411-62]

A. Raicu, Constantza Maritime Univ. (Romania)

8411 IR Synthesis and optical properties of Ni doped $\mathrm{SnO}_{2}$ films [8411-63]

S. Mihaiu, I. Atkinson, M. Gartner, M. Anastasescu, llie Murgulescu Institute of Physical Chemistry (Romania); E. Manea, National Institute for Research and Development in Microtechnologies (Romania); M. Zaharescu, Ilie Murgulescu Institute of Physical Chemistry (Romania)

$84111 \mathrm{U}$ Optical investigations of tin and zinc oxides as TCOs films [8411-66]

A. Toader, S. Mihaiu, M. Voicescu, M. Anastasescu, H. Stroescu, M. Nicolescu, I. Atkinson, M. Gartner, M. Zaharescu, llie Murgulescu Institute of Physical Chemistry (Romania) 
8411 IV Preparation and characterization of GaP colloidal nanoparticles and films [8411-67] M. Iacob, Institute of Chemistry (Moldova); E. Rusu, D. Ghitsu Institute of Electronic Engineering and Nanotechnology (Moldova); S. Pyshkin, Institute of Applied Physics (Moldova) and Clemson Univ. (United States); V. Ursaki, Institute of Applied Physics (Moldova); T. Gutsul, D. Ghitsu Institute of Electronic Engineering and Nanotechnology (Moldova); J. Ballato, Clemson Univ. (United States)

8411 IW Alternative recipes for the removal of fungal colonies affecting historical artifacts [8411-68] R. C. Fierascu, ICECHIM (Romania); I. Fierascu, Politehnica Univ. of Bucharest, ICECHIM (Romania); R. M. Ion, ICECHIM (Romania); R. Dima, Politehnica Univ. of Bucharest (Romania); I. Raut, ICECHIM (Romania)

$84111 \mathrm{X}$ Implementation of a multiple biometric identification system based on face, fingerprints, and iris recognition [8411-69]

P. Stroica, SOEL Systems (Romania); M. Vladescu, Politehnica Univ. of Bucharest (Romania)

$84111 \mathrm{Y}$ Implementation of an omnidirectional surveillance system based on 360-degree panoramic vision [8411-70]

P. Stroica, SOEL Systems (Romania); M. Vladescu, Politehnica Univ. of Bucharest (Romania)

\section{MICROPHOTONICS AND MICRONANOTECHNOLOGIES}

$84111 \mathrm{Z}$ Spectropolarimetry and fluorescence in biotissue's cancer diagnostics (Invited Paper) [8411-71]

S. Yermolenko, Chernivtsi National Univ. (Ukraine); I. Gruia, Univ. of Bucharest (Romania); C. Gavrila, Technical Univ. of Civil Engineering (Romania); M. Gruia, Institute of Oncology (Romania); P. Ivashko, Chernivtsi National Univ. (Ukraine)

841120 R12 freon condensation in micro- and nano-channels of a miniature heat exchanger (Invited Paper) [8411-72]

I. Mihai, L. Patuleanu, C. Suciu, Ştefan cel Mare Univ. of Suceava (Romania)

841121 Integrated filter based on photonic crystals with 2D periodicity [8411-73]

O. Miță, C.-G. Bostan, P. Şchiopu, Politehnica Univ. of Bucharest (Romania)

841123 Laser effects on the oscillator strength for the intraband transitions in $\mathrm{CdS} / \mathrm{SiO}_{2}$ quantum dots [8411-75]

A. Radu, Politehnica Univ. of Bucharest (Romania)

841124 Aluminum nanoparticles production with laser ablation in liquids [8411-76] C. Udrea, M. Bojan, I. Iordache, I. Apostol, V. Damian, National Institute for Lasers, Plasma and Radiation Physics (Romania)

841128 Optical analyses of pulsed interferometric patterning of azo-polysiloxanes [8411-80] V. Damian, I. Apostol, National Institute for Lasers, Plasma and Radiation Physics (Romania); N. Hurduc, Technical Univ. of Iasi (Romania); M. Bojan, C. Udrea, National Institute for Lasers, Plasma and Radiation Physics (Romania)

841129 A spectroscopic and theoretical study of the laser ablation rate of Al [8411-81] M. Stafe, C. Negutu, A. N. Ducariu, N. N. Puscas, Politehnica Univ. of Bucharest (Romania) 
$84112 \mathrm{~A}$ Biofunctionalization of carbon nanotubes with artificial chlorophyll-lipid membranes: spectral characterization [8411-82]

M. E. Barbinta Patrascu, L. Tugulea, Univ. of Bucharest (Romania)

$84112 \mathrm{C}$ Heterojunctions based on transparent oxidic layer and silicon for electronic and optoelectronic device applications [8411-84]

F. C. Comanescu, IMT Bucharest (Romania) and Politehnica Univ. of Bucharest (Romania);

M. Purica, IMT Bucharest (Romania); F. Iacomi, Univ. Alexandru loan Cuza (Romania);

E. Budianu, IMT Bucharest (Romania); P. Schiopu, Politehnica Univ. of Bucharest (Romania)

\section{MODELLING, DESIGN, AND SIMULATION}

$84112 \mathrm{E}$ Modeling of heat transfer in microchannels of a CPU-heat sink cooling system [8411-86]

I. Mihai, C. Suciu, L. Patuleanu, Ştefan cel Mare Univ. of Suceava (Romania)

$84112 \mathrm{~F}$ An operation oriented framework for the integrated development of nanorobots (Invited Paper) [8411-87]

I. Armas, Hyperion Univ. (Romania)

$84112 \mathrm{G}$ Effects of doping concentrations on the photocurrent and dark current of a CMOS photodiode [8411-88]

A. Drăgulinescu, Politehnica Univ. of Bucharest (Romania); L. Lizarraga, S. Mir, TIMA Lab. (France)

841121 Low cost adaptive underwater acoustic modem for the Black Sea environment [8411-90] G. Zărnescu, Constanta Maritime Univ. (Romania)

$84112 \mathrm{~J}$ Comparative resolution analysis between the functionality of the human eye and of the achromatic doublet (Invited Paper) [8411-91]

F. Toadere, Technical Univ. of Cluj Napoca (Romania)

$84112 \mathrm{~K} \quad$ Analyzing the functionality of a scanner [8411-92]

F. Toadere, Technical Univ. of Cluj Napoca (Romania)

$84112 \mathrm{~N}$ Interplay between experimental and numerical approaches in botanical studies: development of a hybrid REC inverse method with application in mycology [8411-95] E. D. Kovacs, R. Trambitas, A. L. Imre, Babeş-Bolyai Univ. (Romania); M. H. Kovacs, National Institute for Research and Development of Isotopic and Molecular Technologies (Romania); D. Ristoiu, Babeş-Bolyai Univ. (Romania)

841120 Pulse-matched synthesis of multiple wire antennas for ultra-wide-band applications [8411-96]

R. D. Tamas, G. Caruntu, Constanta Maritime Univ. (Romania); T. Petrescu, Politehnica Univ. of Bucharest (Romania)

$84112 \mathrm{P}$ Design optimization for time-domain, pulse-matched synthesized antennas [8411-97] R. D. Tamas, Constanta Maritime Univ. (Romania); T. Petrescu, Politehnica Univ. of Bucharest (Romania); G. Caruntu, Constanta Maritime Univ. (Romania) 
$84112 Q \quad$ An improved method for IR image filtering [8411-98]

G. Gavriloaia, Univ. of Pitesti (Romania); C. Neamtu, Ministry of National Defence

(Romania); M.-R. Gavriloaia, Univ. of Medicine and Pharmacy (Romania)

$84112 R \quad$ Chirp signal analysis with amplitude modulation [8411-99]

G. Gavriloaia, Univ. of Pitesti (Romania); C. Neamtu, Ministry of National Defence

(Romania); M.-R. Gavriloaia, Univ. of Medicine and Pharmacy (Romania)

841125 A new method for shape assessment of buried objects [8411-100]

C. Neamtu, Ministry of National Defence (Romania); M.-R. Gavriloaia, Univ. of Medicine and Pharmacy (Romania); G. Gavriloaia, Univ. of Pitesti (Romania)

$84112 \mathrm{~T}$ Modeling of spectral output and spectral responsivity of optoelectronic devices for PSpice simulation [8411-101]

M. Vladescu, Politehnica Univ. of Bucharest (Romania); D. T. Vuza, Institute of Mathematics (Romania)

$84112 \mathrm{U}$ Influence of stochastic processes on kinetics of two-electron transfer in dimer nanocluster embedded in organic matrix [8411-102]

O. V. Yaltychenko, E. Yu. Kanarovskii, Institute of Applied Physics (Moldova)

$84112 \mathrm{~V}$ Modeling approach of ${ }^{13} \mathrm{C}$ isotope separation column for mission critical situations detection [8411-103]

M. L. Boca, B. Croitoru, 1 Decembrie 1918 Univ., Alba lulia (Romania); M. Abrudean,

Technical Univ. of Cluj Napoca (Romania)

$84112 \mathrm{X}$ Modeling of the polarized light scattering in biotissues by Monte Carlo and photon tracing methods [8411-105]

S. Yermolenko, Chernivtsi National Univ. (Ukraine); I. Gruia, Univ. of Bucharest (Romania);

P. Ivashko, O. Prydij, Chernivtsi National Univ. (Ukraine)

$84112 \mathrm{Y}$ Thermal investigations on high power LEDs [8411-106]

C. Ionescu, A. Drumea, N.-D. Codreanu, A. Vasile, Politehnica Univ. of Bucharest

(Romania)

$84112 Z$ Design and simulation of dielectric-loaded surface plasmon waveguides with applications in the visible range [8411-107]

R. Tomescu, C. Kusko, D. Cristea, IMT Bucharest (Romania); P. Schiopu, Politehnica Univ. of Bucharest (Romania)

$841130 \quad$ Electric propulsion [8411-108]

V.-V. Ciucur, Constanta Maritime Univ. (Romania)

841131 Numerical simulation for the study of cavitation for centrifugal pump [8411-126]

S. L. Constantin, Constanta Maritime Univ. (Romania)

Author Index 


\title{
Conference Committee
}

\author{
Conference Chairs
}

Paul Schiopu, Politehnica University of Bucharest (Romania)

Cornel Panait, Constanta Maritime University (Romania)

Violeta-Vali Ciucur, Constanta Maritime University (Romania)

Ionica Cristea, Politehnica University of Bucharest (Romania)

Marian Vladescu, Electromagnetica Goldstar S.R.L. (Romania)

Scientific Committee

Oleg Angelsky, Chernivtsi National University (Ukraine)

Erchin Serpedin, Texas A\&M University (United States)

Mihail S. lovu, Institute of Applied Physics (Moldova)

Daniela Reyna, LAAS-CNRS INSA, Toulouse (France)

Philippe Arguel, LAAS-CNRS INSA, Toulouse (France)

Radu Malureanu, Technical University of Denmark (Denmark)

Violeta-Vali Ciucur, Constanta Maritime University (Romania)

Ioan Ileană, University of Alba-lulia (Romania)

Nicolae A. Enaki, Institute of Applied Physics (Moldova)

Tiberiu Tudor, University of Bucharest (Romania)

Alexandru Stancu, Alexandru loan Cuza University (Romania)

Dan Apostol, National Institute for Lasers, Plasma and Radiation Physics (Romania)

Vasile Sârbu, Ovidius University (Romania)

Henri Arsenault, Laval University (Canada)

Cornel Panait, Maritime University of Constanta (Romania)

Adrian Rusu, Politehnica University of Bucharest (Romania)

Ciupina Victor, Ovidius University (Romania)

Paul Schiopu, Politehnica University of Bucharest (Romania)

George Caruntu, Constanta Maritime University (Romania)

Gheorghe Gavriloaia, University of Pitesti (Romania)

Raluca Muller, National Institute for Research and Development in Microtechnologies (Romania)

Ileana Cernica, National Institute for Research and Development in Microtechnologies (Romania)

Eugene Curatu, AlconLaboratories (United States)

Mihaela Cezarina Hîncu, Ovidius University (Romania)

Rodica Mehedinti, Ovidius University (Romania)

Adrian Manea, Politehnica University of Bucharest (Romania)

Niculae N. Puşcaş, Politehnica University of Bucharest (Romania) 
Lucian Balut, Constanta Maritime University (Romania)

George Stanciu, Politehnica University of Bucharest (Romania)

Constantin Grigoriu, National Institute for Lasers, Plasma and

Radiation Physics (Romania)

Emil Oanta, Constanta Maritime University (Romania)

Dan Popa, Constanta Maritime University (Romania)

Marian Vladescu, Politehnica University of Bucharest (Romania)

Program Committee

Oleg Angelsky, Chernivtsi National University (Ukraine)

C. Yu. Zenkova, Chernivtsi National University (Ukraine)

Radu Malureanu, Technical University of Denmark (Denmark)

Mihail S. lovu, Institute of Applied Physics (Moldova)

Nicolae A. Enaki, Institute of Applied Physics (Moldova)

Gheorghe Gavriloaia, University of Pitesti (Romania)

Niculae Puscas, Politehnica University of Bucharest (Romania)

Paul Schiopu, Politehnica University of Bucharest (Romania)

Razvan Tamas, Constanta Maritime University (Romania)

George Caruntu, Constanta Maritime University (Romania)

Alexandru Vasile, Politehnica University of Bucharest (Romania)

Neculai Grosu, Politehnica University of Bucharest (Romania)

Marian Vladescu, Politehnica University of Bucharest (Romania)

Adrian Manea, Politehnica University of Bucharest (Romania)

Ionica Cristea, Politehnica University of Bucharest (Romania)

Session Chairs

1 Diffractive, Micro-Optics, and Optical Signal Processing

Yu. A. Ushenko, Chernivtsi National University (Ukraine)

Petre C. Logofatu, National Institute for Lasers, Plasma and Radiation

Physics (Romania)

2 Sensors, Microsystems, and Instruments

Radu Malureanu, Technical University of Denmark (Denmark)

Neculai Grosu, Politehnica University of Bucharest (Romania)

3 Advanced Materials and New Technologies

Mihail S. lovu, Institute of Applied Physics (Moldova)

Niculae N. Puşcaş, Politehnica University of Bucharest (Romania)

4 Microphotonics and Micronanotechnologies

Nicolae A. Enaki, Institute of Applied Physics (Moldova)

Sergey Yermolenko, Chernivtsi National University (Ukraine) 
5. Modelling, Design, and Simulation

Marian Vladescu, Politehnica University of Bucharest (Romania)

loana Armas, Hyperion University (Romania)

Razvan Tamas, Maritime University of Constanta (Romania)

George Caruntu, Constanta Maritime University (Romania) 
Proc. of SPIE Vol. $8411841101-14$

Downloaded From: https://www.spiedigitallibrary.org/conference-proceedings-of-spie on 26 Apr 2023 Terms of Use: https://www.spiedigitallibrary.org/terms-of-use 


\section{Introduction}

The sixth edition of the International Conference on Advanced Topics in Optoelectronics, Microelectronics and Nanotechnologies (ATOM-N 2012) is widely recognized as the international forum for gathering the community of scientists and engineers working in research and technology.

It is indeed a unique opportunity to bring together atomic, molecular physicists, physical chemists, biophysicists and scientists developing new tools, methodologies and techniques, all working on the advanced materials and new technologies.

For this edition we received over 116 abstracts from all over Europe and USA. Due to the efforts of the Scientific and Program Committee, 104 papers by authors from 10 countries were selected for presentation: five invited lectures, 43 oral lectures, and 56 poster papers.

We hoped that you enjoyed the conference and venue, where you met friends and colleagues and attended many high-quality technical activities as well as very enjoyable social ones. All conference committees worked hard to make this conference a remarkable and unforgettable event.

We would like to express our thanks to the Organizing Committee for their enthusiastic and efficient work. We extend our warmest thanks to all authors that attended to present their scientific contributions.

Paul Schiopu 
Proc. of SPIE Vol. $8411841101-16$

Downloaded From: https://www.spiedigitallibrary.org/conference-proceedings-of-spie on 26 Apr 2023 Terms of Use: https://www.spiedigitallibrary.org/terms-of-use 